\title{
Big News: The Indian Media and Student Attacks in Australia ${ }^{1}$
}

\author{
Matt Wade \\ Sydney Morning Herald
}

I'd just finished interviewing a flinty, north Indian farmer named Kulbhushen Sharma in September 2009 when he looked me in the eye and asked a probing question: 'Why are our people being attacked in Australia?' Like tens of millions of people across the subcontinent, Mr Sharma had seen dramatic television reports about assaults on Indian students in Australia. His question showed how deeply the negative perceptions of Australia, created by media reports of the attacks, had infiltrated the Indian community. The safety of Indian students in Australia wasn’t just a concern for urban elites with relatives studying abroad. Here was proof that the issue had registered in remote villages as well.

Attacks on foreign students in Australia became one of the biggest news stories in India during 2009 and early 2010. According to John McCarthy, Australia's High Commissioner to India when the crisis flared, 'you had to live in India to see what a big deal it was - I don't think it's ever quite sunk in for people in Australia how much this issue caught the public imagination' (McCarthy et al. 2012). The portrayal of attacks on foreign students in Australia underscored the growing social and political influence of India's media, especially television news. The intense media coverage of the attacks left Australia's reputation in India greatly tarnished. The episode strained relations between India and Australia and triggered a sweeping overhaul of Australia's international education system. I was the Delhi-based correspondent for the The Age and the Sydney Morning Herald newspapers at the time of the student crisis and reported on the public and political reaction to it. This paper will draw

\footnotetext{
${ }^{1}$ This is a non-refereed contribution.

Cosmopolitan Civil Societies Journal, Vol.7, No.3, 2015

ISSN: 1837-5391; https://epress.lib.uts.edu.au/journals/index.php/mcs

CCS Journal is published under the auspices of UTSePress, Sydney, Australia
} 
together some observations about the nature of the Indian media, explore why the student attack story gained so much momentum in India and examine how Australian officials sometimes made matters worse.

\section{The Media Landscape in India}

With more than 70,000 newspapers and over 500 satellite television channels, India has one of the most competitive media markets in the world. Explosive growth in the media industry, especially in television broadcasting, followed an historic program of economy-wide reforms announced by the Indian Government in 1991. Less than two decades ago the dowdy stateowned broadcaster, Doordarshan, had a virtual monopoly over television news. Now more than $100 \mathrm{CNN}$-style news channels operate around the clock in English, Hindi and at least 10 other regional languages. Most of India's major states have at least three or four, if not more, news channels, and the majority are accessible nationwide. Almost 150 million households have a television and receive programs via free-to-air, cable and digital direct-to-home platforms. In 2012, digital media penetration soared by 63 per cent to 42 million households (McCarthy et al. 2012).

Intense competition for viewers has contributed to a sensationalist television news culture in India which emphasises political controversy and conflict. Medcalf (2009) says the Indian media has developed an unmatched ability ‘to make a story huge, and to keep it that way'. Many news channels in India have adopted a highly nationalistic editorial stance reminiscent of America’s Fox News broadcasting model. According to Malik \& Medcalf,

Their coverage of India's place in the world is touched by jingoism. In middle India this often has bizarre consequences, as the news channels can be the typical provincial news consumer's only window to the outside world (2011, p. 12).

Despite its reputation for sensationalism, the public has considerable trust in the Indian media. The India-Australia Poll 2013, conducted by the Lowy Institute for International Policy and the Australia India Institute, found 86 per cent of respondents believed the Indian media accurately reported events in India and 83 per cent believed it accurately reported world events (Medcalf 2013). 


\section{The Indian Media's Coverage of Student Attacks in Australia}

The safety of foreign students in Australia caught the Indian media's attention in May 2009. The timing of two assaults in Melbourne, and the imagery associated with them, were important factors in the development of the story. A closed circuit security camera on a Melbourne train carriage played an especially important role. It recorded graphic television images of 21-year-old Indian student, Sourabh Sharma, being brutally bashed on the night of May 9, 2009. Victorian police released video footage of the attack about 10 days after the incident and this was soon broadcast by news outlets in Australia and India. The chilling images caused understandable outrage in India - it showed Mr Sharma being repeatedly punched and kicked by a gang of five hooded youths. One attacker rifles through his bag, taking a phone and a significant amount of cash. He appears to laugh after kicking the victim. Television news channels in India broadcast the frightening pictures on high rotation for many days after their release. Photographs of Mr Sharma’s badly bruised face were also published and broadcast frequently. A few days after the train attack video was released, another Indian student, 25-year-old Shravan Kumar, was stabbed in the head with a screwdriver during an attack in Melbourne. Disturbing photographs of Mr Kumar unconscious in hospital with tubes coming from his nose and mouth stoked the media frenzy over the safety of Indian students in Australia. The dramatic images of violence were tailormade for India's influential cable news channels and they were recycled frequently in the months that followed. As subsequent reports of assaults on Indians in Australia emerged during 2009, the images of the assaults on Sourabh Sharma and Shravan Kumar were shown repeatedly to large television audiences in India.

The timing of these initial attacks was significant. They occurred during a rare lull in the Indian media cycle. It was the peak of summer in India and interest in the year's biggest story - the 2009 general election - was beginning to fade. The violent incidents in Melbourne handed Indian television news directors a new storyline: 'Racist Australia'. Reports about the attacks - especially on television - routinely portrayed them as racially motivated. For months after the story broke, the Times Now television network had a featured link on its website entitled 'Racism Beyond Shame’. In late July 2009 it linked to more than 50 television reports about attacks on Indian students and problems faced by foreign students in Australia. Pramit Pal Chaudhuri, a Delhi-based foreign policy specialist and senior editor at the Hindustan Times newspaper, says the story probably would have passed relatively unnoticed had the events happened during the Indian elections a month earlier. 
It was a story made for television... when nothing else much was going on. But if it had happened during the Indian election people would have paid much less attention (Chaudhuri 2009).

The nature of the story also contributed to its wide appeal. Indian television historian, Nalin Mehta, said it resonated with the country's burgeoning urban middle class - the key audience for India's news media - where there is a strong perception that the country is an emerging power and that its citizens should be treated with great respect:

It had an element of middle-class students being victimised, it also had elements of racial and national pride. That's what made the story so sexy for channels targeting India's primary viewing audience (Mehta 2009).

Millions of middle-class families in India either have a relative studying abroad or aspire to send a family member to study overseas. As a result, media reports about Indian students being mistreated struck a chord with a key audience for India’s burgeoning television market. Scores of mass circulation newspapers and news websites also provided comprehensive coverage of the attacks in multiple languages.

The Indian media's interest in the issue of student safety in Australia was sustained for an unusually long period, with two distinct peaks. The first peak was between May and July of 2009 and the second followed the January 2010 knifing murder of Indian national, Nitin Garg, in Melbourne. New, low-cost communication technologies and social media played a role in drawing attention to student attacks in Australia and sustaining the Indian media's interest in the issue. In some cases Indian students used smartphone cameras and text messages to supply Indian media with information about the experience of international students in Australia. Those claiming to speak on behalf of Indian students in Australia were frequently interviewed on Indian television via a skype video link. These technologies allowed Indian television channels relatively easy, inexpensive access to those willing to speak about the issue in Australia, even when they did not have their own reporters based there.

In February 2010, more than eight months after video images of the attack on Sourabh Sharma were first broadcast, the influential Indian weekly news magazine, Outlook, ran the provocative headline on its front cover: 'Why the Aussies hate us'. The edition featured a 10page special report including stories and photographs of Indians who had experienced violence and racial abuse in Australia. It claimed to have found 'evidence that "curry-bashing” 
is becoming a fun game for white Australians' and quoted the leader of an ultra-nationalist political party saying Indians were 'becoming a serious threat to white Australians in the job market'. Van Thanh Rudd, an anti-racism activist and nephew of the then Prime Minister Kevin Rudd, told Outlook the 'dominant culture in Australia' was racist, and that many of the attacks on Indian students had been racially motivated. When I interviewed Outlook's editorin-chief, Vinod Mehta, about the report, he defended the magazine's coverage of the issue and denied allegations that the Indian media was overreacting to events in Australia. 'We sent two correspondents to Australia and they found that an overwhelming number of these incidents were racial and they found that Indians in Australia live in fear', he said. 'There is tremendous outrage in this country. I don't think the Australians realise that' (Mehta 2010).

Another telling indicator of the scale of public interest in the student crisis was the attention it gained from Bollywood. One of the biggest stars in Indian cinema, Amitabh Bachchan, announced he would not accept an honorary doctorate offered to him by the Queensland University of Technology in protest over the treatment of Indian students in Australia. 'Under the present circumstances, where citizens of my own country are subjected to such acts of inhuman horror, my conscience does not permit me to accept this decoration from a country that perpetrates such indignity to my fellow countrymen', he wrote on his blog in May 2009. Mr Bachchan’s decision received a blaze of publicity in India. The student crisis even inspired a Bollywood blockbuster. The film, called Crook, was set in Melbourne against the backdrop of attacks on Indian students. Produced by cinema veteran, Mahesh Bhatt, and starring several well-known Bollywood actors, the Hindi-language movie was released in October 2010. Numerous scenes in the film dramatised violence against Indians; Romper Stomper-style louts in balaclavas brutally beat an Indian student in a parking lot; a Pakistani convenience store owner is knifed by a racist attacker; and an Indian attack victim recovers after being beaten in a bath filled with blood-stained water. Another scene depicts a battered Indian student with facial wounds telling the crowd at a protest march that 'I got this punishment due to my colour - it's because I'm an Indian'. Crook also featured a bigoted policeman in cahoots with racist gang members. Mahesh Bhatt claimed the film was an unflinching examination of the 'burning issue of racism which has devastated the life of thousands of young Indians who go to Australia in search of a better life, putting not only all their money but even their lives at stake' (Bhatt 2010). The portrayal of the attacks in a highprofile example of Indian popular culture was another illustration of how deeply the issue 
infiltrated public perceptions in India. 'Art is a reflection of our society', Bhatt told me. 'This is not the first time that Bollywood is going to mirror society's thoughts in a movie.'

\section{Reactions to the Media's Portrayal of Student Attacks}

More than 115 million Indian households had a television set in 2009 and it is likely that most of them were exposed to bad publicity about Australia as a result of the student attacks. Nalin Mehta (2009) said the story 'redefined the image of Australia for the average TVwatcher in India’. McCarthy et al. (2012) argue the Indian student crisis of 2009-10 exposed Australia to the harsh realities of cultural collision and media image-formation in the era of global migration, business and communications.

In particular, it illustrated how instant, global, television news can sweep away decades of benign perceptions - in this case, Cricket, Commonwealth and Curry - and replace them with a more dramatic, negative counter-narrative (McCarthy et al. 2012, p. 48).

The fervent media coverage of student attacks triggered anti-Australian fury in India. Television news channels received a barrage of angry calls while news websites and blog sites were flooded with comments highly critical of Australia. Many referred to Australia's convict history and some called for tit-for-tat attacks on Australians in India (a senior Western diplomat in India suggested that I get a guard permanently posted outside my house in Delhi amid the public outcry over the student attacks).

In June 2009 members of the Hindu nationalist political movement, the Shiv Sena, and student protesters, burnt effigies of the Australian Prime Minister in the Indian capital, New Delhi. The Hindu nationalist party, Vishwa Hindu Parishad, said it would call for a boycott of Australia if authorities did not do more to protect Hindus in Australia. Television reports also spurred community-level activism, especially in the states of Punjab and Haryana, the home states of many Indians studying in Australia. This put pressure on local members of parliament who began to lobby India's Ministry of External Affairs to take action on the issue.

The media frenzy and intense public reaction over the safety of students in Australia made it difficult for the Indian Government to remain on the sidelines. In August 2009, the then Minister of State for External Affairs, Shashi Tharoor - a former United Nations undersecretary general - told me that the frequency of attacks on students in Australia had raised 
legitimate suspicions in India. The repetitiveness of the attacks had given the issue 'critical mass' in India (Tharoor 2009). India’s Foreign Minister, S.M. Krishna, and Minister of Overseas Indian Affairs, Vayalar Ravi, made regular public statements in 2009 and early 2010 expressing concern about the safety of Indian students in Australia. Amid the media firestorm that followed the murder of Nitin Garg in January 2010, Mr Krishna’s language became more strident. On one occasion he said 'non-redressal of this vital issue will cast a shadow on our otherwise excellent bilateral relations'. He also warned that the Indian Government could advise young people not to go to Australia for study if attacks continued. 'I'm sure that the Australian authorities would take confidence in the fact that India talks softly but when the decisive moment comes India can also act', he said on television.

The response of Indian officials to student attacks in Australia highlighted the influence that India's broadcast media, with is vast audience, can have on the country's foreign relations. McCarthy et al. argue:

The episode was perhaps the earliest example of how the interplay of news television and provincial politics was beginning to affect foreign policy and diplomatic action in India. It was as sobering a lesson for the [Ministry of External Affairs] as it was for foreign countries and diplomats dealing with India (2012, p. 29).

The Australian Government was slow to comprehend the damage Indian news television could inflict on the bilateral relationship with India. In February 2010, Australia’s Defence Minister, Stephen Smith, acknowledged that the student crisis 'cast a long shadow...across our broader relationship and bilateral agenda’ with India. According to Malik \& Medcalf, It is notable that both Indian ministers and their Australian counterparts were forced into breathless reaction by the Indian media's coverage of the 'racism story'. This represents a phenomenon at once noteworthy and worrying. It establishes that news channels are democratising not just India's domestic political debate, but also its global attitudes and the sources of its foreign policy (2011, p. 13).

Media commentary in India often linked the student attacks to other irritants in relations between Australia and India, such as Labor's ban on the export of uranium to India (Labor announced the ban would be lifted in November 2011) and even aggressive behaviour of the Australian cricket team while playing test matches against India. Commentary on the attacks sometimes mentioned the White Australia policy (largely dismantled in the 1960s and 
abolished in the 1970s), the anti-immigration rhetoric of the One Nation party and the wrongful imprisonment of Indian-born doctor Mohammad Haneef in Australia. When Julia Gillard raised concerns about security in the lead up to the 2010 Commonwealth Games in Delhi some media reports linked her remarks to the student attacks.

\section{The Role of Australian Officials}

The Indian media has been accused of sensationalising the violence against Indians in Australia in 2009-10 and exaggerating the danger to foreign students. But Australian officials sometimes added to the negative media coverage of Australia unnecessarily and increased the reputational damage. Once the safety of Indians in Australia had emerged as a matter of public interest in mid-2009, the Indian media closely scrutinised remarks about the issue made by state and federal ministers, police and other officials. Comments by officials about specific incidents and investigations were often broadcast to huge Indian television audiences and forensically examined by Indian journalists and commentators. Malik \& Medcalf point out that:

To many millions of Indians, an officer of the Melbourne police, addressing a local audience, became the spokesperson for all Australia, addressing the world (2011, p. 14).

Indians were often unimpressed by what they heard. Eight months after the safety of Indian students in Australia first made headlines, a report on the popular Times Now website said Australian officials 'never fail to shock' with their remarks on the issue. Three examples illustrate how the reaction of Australian officials sometimes made matters worse; the initial failure to acknowledge racist elements in some attacks; ineffective communication with the media; and ill-advised comments by senior politicians and officials.

The initial failure to acknowledge racist elements in some attacks

Australia's failure to seriously address the racist dimension of the 2009 crisis sparked fears in India of institutional prejudice against Indian students. Australian officials initially described the attacks as 'opportunistic' robberies and played down any racial dimension to them. But this contradicted claims made about the attacks on Indian television. Witnesses to some of the assaults claimed they had heard attackers shouting racial abuse. Those claiming to speak on behalf of Indian students in Australia also linked the attacks to cases of racial vilification. The defensive statements made by Australian officials, and the failure to acknowledge racist 
elements in the attacks, sometimes demanded as much attention from the Indian media as the attacks themselves. Vinod Mehta, the editor of the influential Outlook magazine, told me one reason for the anger over the student attacks was the 'smug and superior attitude of the Australian government for denying there was racism and then telling the Indians not to hype this up' (Mehta 2010).

The perception of a cover-up was especially damaging because it stirred old perceptions of Australia as a racist nation and heightened the fears of Indians who had relatives or friends studying in Australia.

Indians were not interested so much in the gap between reality and perception as Australian officials seemed to be, but in getting credible, detailed information about the crimes and the people affected, the motivations behind those crimes, and what government agencies were doing to stop more crimes being committed. When they didn't get that information, panic set in (McCarthy et al. 2012, p. 43).

\section{Ineffective communication with the media}

There were occasions when better media management by Australian officials might have promoted more accurate reporting of violence against Indians and reduced the damage to Australia's reputation. One telling example followed an attack on two Indian nationals outside a Melbourne pub late on Saturday, September 12, 2009. The Victorian police did not make an immediate statement about the incident and it went unreported by the Australian media. Instead, the high-rating Indian television station Times Now broke the story with an exclusive interview with the alleged victims nearly three days after the incident in Melbourne. They told Times Now that '70 people' were involved in the attack, a claim quickly repeated many times in television and newspaper reports across India. A headline in the Delhi-based newspaper Asian Age was typical of the Indian coverage: 'Oz mob of 70 attacks 3 Indians'. Victorian police eventually refuted this claim, saying four or five people were directly involved in the attack while about 20 looked on. But it was too late. The delay in the official account meant an incident that took place in the suburbs of Melbourne had been framed for tens of millions of Indians by television news editors in Mumbai. The belated response by Victorian police was widely interpreted as an attempt to downplay the significance of the attack and subsequent efforts by Australian officials to set the record straight went largely 
unreported. Times Now continued to report that '70 racist Australians' had bashed the two Indian citizens more than a week after the incident took place.

\section{Ill-advised remarks by senior politicians and officials}

Some remarks made by senior politicians and officials during the student crisis attracted very negative media coverage in India. In July 2009, the then Prime Minister, Kevin Rudd, was lambasted on one of India's most popular television programs after he told an Indian journalist that Indian food had made a major contribution to Australian culture. Arnab Goswami, the editor-in chief of the Times Now channel and presenter of the Newshour program, said Mr Rudd's remarks trivialised the attacks on Indians in Australia. 'Let it be known that Australian Prime Minister Kevin Rudd should do something a bit more serious than give interviews to Indian channels talking about how much he likes Indian food - that's not the point', he said. The Newshour segment was titled 'Take This, Mr Rudd' and it featured a report called 'Yes, it's Racism' about the treatment of Indian students in Australia. There was a similar case in September 2009 when John Brumby, then Premier of Victoria, was visiting India to promote Melbourne as a safe destination for foreign students and tourists. Soon after Mr Brumby’s arrival, Essendon footballer, Michael Hurley, was accused of punching and kicking a taxi driver of Indian origin in Melbourne (Mr Hurley was later charged with assault). Mr Brumby drew fire in the media when he described Mr Hurley as 'a good kid’ during a press conference in New Delhi. Mr Brumby’s remarks were interpreted as a character reference for the alleged attacker which could compromise any subsequent police investigation and judicial process. A report on the Times Now website said Mr Brumby had 'added insult to injury by giving a character certificate to the attacker'.

In February 2010, Simon Overland, then Victoria’s Police Commissioner, triggered an angry reaction in India when he advised international students to 'look poor' to help avoid attacks. Gautam Gupta, secretary of the Federation of Indian Students of Australia, responded to $\mathrm{Mr}$ Overland's advice by saying: 'What is he saying? Indians don't have the right to be rich? And if they look rich, do they maybe have to get bashed?' This and other strong criticisms of $\mathrm{Mr}$ Overland's comments were widely quoted in the Indian media. Some media commentary expressed frustration at the repeated gaffes by Australian officials over the student safety issue. A report on the Times Now website about Mr Overland's remarks said: 
Australian officials never fail to shock with some of their comments on the race attacks down under. But, arguably in the most ridiculous statement so far, the Victoria Police Chief Commissioner has said India students must 'dress to look poor', if they don't want to be targets (Times Now 2010).

\section{Conclusion}

By any measure, 2009 was a big year for news in India. There was a general election - the largest poll in world history given the size of India’s electorate; Prime Minister Manmohan Singh made the first ever official state visit to the White House; and tensions simmered in the aftermath of the November 2008 terrorist assault on Mumbai. And yet the safety of Indian students in Australia ranked among the major news events in India that year. The IndiaAustralia Poll 2013 found 65 per cent of respondents believed the Indian media had accurately reported the problems faced by Indian students in Australia in 2009-10. That implies two-thirds of Indians accepted the Indian media's mostly negative depictions of Australia. Those who believed the media reporting about Australia had been accurate were more likely to be from large cities, be tertiary educated and have relatively high-incomes. The poll found 62 per cent of respondents thought Australia was a dangerous place for Indian students and that 61 per cent believed attacks on Indian students were motivated by racism. The results suggest negative perceptions about Australia created by the media's portrayal of the student attacks linger in the Indian community.

The timing of the initial attacks, and the imagery associated with them, helped attract and sustain media attention on the issue. The story also had significant appeal to India's aspirational middle-class, a key audience for India's complex, fast growing and highly competitive television news business. The public reaction to stories about the safety of Indian students in Australia made it impossible for the Indian Government to ignore the issue. The diplomatic tensions created by the crisis highlighted the growing influence of the broadcast media on India's foreign relations.

But the episode also exposed a deep lack of understanding about India in Australia. Governments were slow to comprehend how much damage media coverage of student attacks could do to Australia's reputation in India. At times Australian officials made matters worse with ill-advised or uniformed remarks. The student crisis showed that Australia still has much to learn about India. 


\section{Interviews}

Bhatt, M. (2010) Interview with the author, October.

Chaudhuri, P. P. (2009) Interview with the author, May.

Mehta, N. (2009) Interview with the author, May.

Mehta, V. (2010) Interview with the author, February.

McCarthy, J. (2012) Interview with the author, July.

Tharoor, S. (2009) Interview with the author, August.

\section{References}

McCarthy, J., Baru,S., Parthasarathy, G., McKew, M., Malik, A. \& Kremmer, C. 2012, Beyond the Lost Decade: Report of the Australia-India Institute Perceptions Taskforce Australia-India Institute, Melbourne.

Malik, A. \& Medcalf, R. 2011, 'India’s New World: Civil Society in the Making of Foreign Policy’, Lowy Institute Analyses, Lowy Institute for International Policy, Sydney. Available from: http://www.lowyinstitute.org/files/pubfiles/Malik_and_Medcalf\%2C_India\%27s_new _world_web.pdf

Medcalf, R. 2009, 'Troubled waters in need of oil', Tehelka, vol. 6, no. 23, June 13. 2013, 'India-Australia Poll 2013’, Lowy Institute for International Policy, Sydney \& Australia-India Institute, Melbourne. Available from:

http://www.lowyinstitute.org/publications/india-australia-poll-2013

Outlook 2010, February 8.

Times Now 2010, ‘Aus police’s bizarre remedy for Indians’, February 7, available from http://www.timesnow.tv/articleshow/4338002.cms 